\title{
Prevalence of the C677T substitution of the methylenetetrahydrofolate reductase (MTHFR) gene in Wisconsin
}

\author{
Zhongxia Qi, PhD ${ }^{3}$, Gary Hoffman, BS ${ }^{1}$, Daniel Kurtycz, $M D^{1,2,}$ and Jingwei $Y u, M D, P h D^{1,2,3}$
}

\begin{abstract}
Purpose: The objective of this study was to estimate the prevalence of the C677T substitution of the MTHFR gene in the State of Wisconsin. Methods: The MTHFR genotypes of 1059 randomly selected newborns were analyzed using PCR amplification, Hinfl restriction enzyme digestion, and electrophoresis. The frequency of the substitution was calculated in different genders and statistically analyzed (Chi-square). Results: Among 1059 newborn infants, about $59 \%$ had a C/C homozygous genotype, $33 \%$ had a C/T heterozygous genotype, and the remaining $8 \%$ had a T/T homozygous genotype. The frequencies for the $C$ and T alleles were $76 \%(p)$ and $24 \%(q)$, respectively. There were no significant differences between males and females. Conclusion: The study provides a fair estimate for the prevalence of the C677T substitution of the MTHFR gene in the general population in Wisconsin, which will facilitate further investigations of the pathogenic effects of the gene. Genet Med 2003:5(6):458-459.
\end{abstract}

Key Words: 5,10-methylenetetrahydrofolate reductase, C677T substitution, genotype, allele frequency, newborn

5,10-Methylenetetrahydrofolate reductase (MTHFR) is an essential enzyme in folate metabolism, which catalyzes the 5,10-methylenetetrahydrofolate to 5-methyltetrahydrofolate reduction. The later provides a methyl group in conversion of homocysteine to methionine that is an important precursor for synthesis of protein and S-adenosyl-L-methionine (SAM), the universal methyl donor for methylation. ${ }^{1-3}$ The MTHFR gene is located on the short arm of chromosome 1 at $1 \mathrm{p} 36.3$, and consists of 11 exons. ${ }^{1}$ Several common nucleotide polymorphisms in this gene have been reported, one of which is a $\mathrm{C}$ to T substitution at the position 667 (C677T) in the exon 4, resulting in an alanine (Ala) to valine (Val) conversion at the amino acid 225 in the protein product. ${ }^{3,4}$ The MTHFR protein coded by the $\mathrm{T}$ allele is thermolabile with reduced enzyme activity at $37^{\circ} \mathrm{C} .{ }^{4}$ Such a deficiency appears to have pathogenic importance, especially with decreased folate intake and other genetic/environmental factors. ${ }^{1,3,5}$ The C667T substitution has been associated with elevated plasma homocysteine concentration and genome hypomethylation, as well as increased risk for vascular disease, neural tube defects, diabetes, preeclampsia, and Down syndrome. ${ }^{1,5-7}$ In addition, this substitution has been studied for its relation to cancer, longevity, and drug toxicity. ${ }^{1,8,9}$ Thus far, the epidemiology information related to this substitution in the general population is limited; for example,

\footnotetext{
From ${ }^{1}$ Wisconsin State Laboratory of Hygiene, ${ }^{2}$ Department of Pathology and Laboratory Medicine, and ${ }^{3}$ Waisman Center, University of Wisconsin-Madison, Madison, Wisconsin.

Jingwei Yu, MD, PhD, Waisman Center, Room 213, University of Wisconsin-Madison, 1500 Highland Avenue, Madison, WI 53705.

Received: June 13, 2003.

Accepted: August 4, 2003.
}

DOI: 10.1097/01.GIM.0000095001.12570.A8 to our knowledge no such information is available in the Midwest States of the United States. To study the pathogenic effect of the C677T substitution and its possible impact on related health issues in a geographic region, knowing the prevalence of this substitution in the general population of the region is essential. In this study, we have looked at the frequency of the C677T substitution of the MTHFR gene in 1059 randomly selected newborn infants in the State of Wisconsin, which provides an estimate of the prevalence of the substitution in the state.

\section{MATERIALS AND METHODS}

A total of 1059 dried blood (Guthrie) spot specimens from infants born in Wisconsin from October 2002 to April 2003 were randomly selected from those received by the newborn screening laboratory at the Wisconsin State Laboratory of Hygiene. DNA samples were extracted by prewashing the spots with phosphate buffered saline and then incubated with TE buffer at $96{ }^{\circ} \mathrm{C}$ for 30 minutes. The genotype of each subject was examined using a PCR/restriction digestion-based method. ${ }^{4}$ Briefly, about 50 to $80 \mathrm{ng}$ DNA sample was amplified in a final volume of $25 \mu \mathrm{L}$ containing $1 \times$ PCR buffer with 1.5 $\mathrm{mmol} / \mathrm{L} \mathrm{MgCl}_{2}, 2$ unit Taq DNA polymerase (Eppendorf), 100 $\mu \mathrm{mol} / \mathrm{L} \mathrm{dNTP}$, and $0.5 \mu \mathrm{mol} / \mathrm{L}$ of each primer $\left(5^{\prime}\right.$-tgaaggagaaggtgtctgcggga- $3^{\prime}$ and $5^{\prime}$-aggacggtgcggtgagagtg-3'). On a Perkin-Elmer 9600 thermocycler, the DNA sample was first denatured at $94^{\circ} \mathrm{C}$ for 3 minutes, and then amplified for 35 cycles of $94^{\circ} \mathrm{C} 30$ seconds, $55^{\circ} \mathrm{C} 30$ seconds, and $72^{\circ} \mathrm{C} 1$ minute, followed by an extension at $72^{\circ} \mathrm{C}$ for 10 minutes. The PCR product was digested with HinfI (New England Biolabs) at $37^{\circ} \mathrm{C}$ overnight, separated by electrophoresis on $4 \% 3: 1$ 
Table 1

Prevalence of the C677T substitution of the MTHFR gene in Wisconsin

\begin{tabular}{|c|c|c|c|c|c|c|}
\hline & \multirow[b]{2}{*}{ No. } & \multicolumn{3}{|c|}{ Genotype } & \multicolumn{2}{|c|}{ Allele Frequency } \\
\hline & & $\mathrm{C} / \mathrm{C}$ & $\mathrm{C} / \mathrm{T}$ & $\mathrm{T} / \mathrm{T}$ & $\mathrm{C}(p)$ & $\mathrm{T}(q)$ \\
\hline Female & 541 & $316(58 \%)$ & $177(33 \%)$ & $48(9 \%)$ & $75 \%$ & $25 \%$ \\
\hline Male & 518 & $310(60 \%)$ & $170(33 \%)$ & $38(7 \%)$ & $76 \%$ & $24 \%$ \\
\hline Total & 1059 & $626(59 \%)$ & $347(33 \%)$ & $86(8 \%)$ & $76 \%$ & $24 \%$ \\
\hline
\end{tabular}

NuSieve/agarose gel (FMC), and visualized by ethidium bromide staining. A 201-bp PCR product can be seen in a $\mathrm{C}$ allele; whereas, C677T substitution creates a HinfI restriction enzyme recognition site within the sequence of the PCR product, resulting in 178-bp and 23-bp fragments. The fragment pattern of each individual was analyzed and recorded for calculation of genotype and allele frequencies. A Chi-square analysis of the frequency differences between males and females was performed.

\section{RESULTS AND DISCUSSION}

Our results demonstrated that about 59\% of 1059 newborn infants analyzed had a $\mathrm{C} / \mathrm{C}$ homozygous genotype, $33 \%$ had a heterozygous $\mathrm{C} / \mathrm{T}$ genotype, and the remaining $8 \%$ had a homozygous $\mathrm{T} / \mathrm{T}$ genotype; the frequencies for the wild-type allele $\mathrm{C}$ and the deficient allele $\mathrm{T}$ were $76 \%(p)$ and $24 \%(q)$, respectively (Table 1 ). There were no significant differences of allele frequencies or genotype distributions between males and females, apparently contradicting previous reports that female newborns had a lower proportion of C677T homozygosity than male newborns. ${ }^{10}$ Because the frequency of the C677T substitution varies among different ethnic and geographic populations, ${ }^{3,11}$ the prevalence of this substitution in Wisconsin may only be accurately estimated using unbiased samples from the general population of the state. According to the US Census Bureau's data, the vast majority of the Wisconsin population are non-Hispanic/Latino origin Caucasians (87.3\% in 2000). ${ }^{12}$ The newborn screening laboratory at the Wisconsin State Laboratory of Hygiene tests every infant born in Wisconsin. Therefore, randomly selected newborns should be representative of the ethnic distribution in the state, and our data should provide a fair estimate for the prevalence of the C677T substitution in Wisconsin. This estimated prevalence is different from most of those reported in other regions of the United States, but similar to that in a Canadian population. ${ }^{3,11,13}$ The information provides a unique and useful reference for further studies of the MTHFR gene in the state, such as the genotypephenotype correlation in different disease and age groups. It is also useful for complementing those obtained through epidemiological studies from other geographic and ethnic groups.
In addition, these data may also be valuable for public health agencies and clinical facilities to develop appropriate strategies of prevention and management of diseases that may be associated with the deficiency of the MTHFR gene in the State of Wisconsin.

\section{ACKNOWLEDGMENT}

We thank Gregory Kopish and Jinna Shu (Wisconsin State Laboratory of Hygiene) for their excellent technical assistance and Yuan Tian (Department of Statistics, UW-Madison) for the help on statistical analysis.

\section{References}

1. Födinger M, Hörl WH, Sunder-Plassmann G. Molecular biology of 5,10-methylenetetrahydrofolate reductase. J Nephrol 2000;13:20-33.

2. Rosenblatt DS. Methylenetetrahydrofolate reductase. Clin Invest Med 2001;24:5659.

3. Botto LD, Yang Q. 5, 10-Methylenetetrahydrofolate reductase gene variants and congenital anomalies: A HuGE review. Am J Epi 2000;151:862-877.

4. Frosst P, Blom HJ, Milos R, Goyette P, Sheppard CA, Matthews RG et al. A candidate genetic risk factor for vascular disease: a common mutation in methylenetetrahydrofolate reductase. Nat Genet 1995;10:111-113.

5. Friso S, Choi S, Girelli D, Mason JB, Dolnikowski GG, Bagley PJ et al. A common mutation in the 5,10-methylenetetrahydrofolate reductase gene affects genomic DNA methylation through an interaction with folate status. Proc Natl Acad Sci U S A 2002;99:5606-5611.

6. Castro R, Rivera I, Ravasco P, Jakobs C, Blom HJ, Camilo ME et al. 5, 10-methylenetetrahydrofolate reductase $677 \mathrm{C} \rightarrow \mathrm{T}$ and $1298 \mathrm{~A} \rightarrow \mathrm{C}$ mutations are determinants of elevated homocysteine. Q J Med 2003;96:297-303.

7. Hobbs CA, Cleves MA, Lauer RM, Burns TL, James SJ. Preferential transmission of the MTHFR 677T allele to infants with Down syndrome: Implication for a survival advantage. Am J Med Genet 2002;113:9-14.

8. Heijmans BT, Boer JMA, Suchiman HED, Cornelisse CJ, Westendorp RGJ, Kromhout $\mathrm{D}$ et al. A common variant of the methylenetetrahydrofolate reductase gene (1p36) is associated with an increased risk of cancer. Cancer Res 2003;63:1249-1253.

9. Toffoli G, Russo A, Innocenti F, Corona G, Tumolo S, Sartor F et al. Effect of methylenetetrahydrofolate reductase $677 \mathrm{C} \rightarrow \mathrm{T}$ polymorphism on toxicity and homocysteine plasma level after chronic methotrexate treatment of ovarian cancer patients. Int J Cancer 2003;103:294-299.

10. Rozen R, Fraser FC, Shaw G. Decreased proportion of female newborn infants homozygous for the $677 \mathrm{C} \rightarrow \mathrm{T}$ mutation in methylenetetrahydrofolate reductase. Am J Med Genet 1999;83:142-143.

11. Esfahani ST, Cogger EA, Caudill MA. Heterogeneity in the prevalence of methylenetetrahydrofolate reductase gene polymorphisms in women of different ethnic groups. J Am Diet Assoc 2003;103:200-207.

12. U.S. Census Data, 2000. Available at: http://quickfacts.census.gov. Accessed September 22, 2003.

13. Mogk RL, Rothenmund H, Evans JA, Carson N, Dawson AJ. The frequency of the C677T substitution in the methylenetetrahydrofolate reductase gene in Manitoba. Clin Genet 2000;58:406-408. 